(Received March 7, 1977)

\title{
PROPERTIES OF DECRYSTALLIZED COTTON PREPARED BY ALKALI-ACRYLONITRILE TREATMENT
}

\author{
By Asako Hirai, Waichiro Tsuji * and Masao Hosono \\ (Institute for Chemical Research, Kyoto University, \\ Uji, Kyoto-Fu 611, Japan)
}

\begin{abstract}
Synopsis
Highly accessible and decrystallized cotton can be prepared by cyanoethylation with acrylonitrile after pretreatment with swelling agents. In this research, cotton fabrics with or without chemical crosslinkages were treated with acrylonitrile after impregnation with $5.4 \mathrm{~N}$ aqueous sodium hydroxide solution, and some physical properties of the treated cotton were examined. Fairly high moisture regains were obtained. The abrasion resistance of cotton fabrics was increased by the alkaliacrylonitrile treatment. The tensile strength, elongation and moisture regain of treated fabric were increased when the alkali-acrylonitrile treatment was given to chemically crosslinked cotton fabrics, although a small loss in dry crease recovery was caused.
\end{abstract}

\section{Introduction}

As already reported, ${ }^{1,2}$ highly accessible or decrystallized cotton could be obtained by cyanoethylation with acrylonitrile after pretreatment with swelling agent such as sodium hydroxide. The fine structure of the cotton thus decrystallized was also investigated by $x$-ray diffraction studies. ${ }^{3}$ In the present research, cotton fabrics with or without chemical crosslinkages were treated with acrylonitrile after impregnation with $5.4 \mathrm{~N}$ aqueous solution of sodium hydroxide, and some physical properties of the treated cotton fabrics were examined. In this process a small quantity of cyanoethyl residue was introduced onto cellulose molecules to prevent recrystallization during water rinse and drying. Crosslinking was given to cotton fabrics before or after the decrystallization process, using conventional crosslinking agents.

As is well-known, the deterioration of the mechanical properties of cotton, such as tensile strength and abrasion resistance, caused by the crosslinking finishing, is a serious problem in washand-wear finishing of cotton fabrics.

When intermolecular crosslinking are given to

* Present address: Mukogawa Women's University, Ikebiraki, Nishinomiya, Hyogo-Ken 663. Japan. cotton cellulose chains in amorphous region, the mobility of molecular segments is so greatly restricted that decrease of tensile strength may be caused. Therefore, if the degree of crystallinity is decreased or the accessibility is increased, the tensile stress is distributed more uniformly and decrease of tensile strength of cotton by crosslinking will be minimized. ${ }^{4}$

\section{Experimental}

Sample. Scoured and bleached $40^{\prime}$ s cotton fabric (plain weave) supplied by Toyo Spinning Co. was used.

Treatment with Alkali. Sample fabrics were immersed in $5.4 \mathrm{~N}$ aqueous solution of sodium hydroxide for $30 \mathrm{~min}$ at $15^{\circ} \mathrm{C}$ without tension. Then after being squeezed, they were washed with water, immersed in $0.2 \%$ acetic acid, washed again with water and air-dried.

Treatment with Alkali and Acrylonitrile. Sample fabrics were immersed in $5.4 \mathrm{~N}$ aqueous sodium hydroxide solutions for $30 \mathrm{~min}$ at $15^{\circ} \mathrm{C}$. After being squeezed, they were immersed in acrylonitrile at $20^{\circ} \mathrm{C}$, squeezed, immersed in $0.2 \%$ acetic acid, washed with water, and air-dried. Fabrics were treated without tension.

Nitrogen Analysis. Nitrogen contents (\%N) of 
fabrics treated with acrylonitrile were determined by micro-Kjeldahl method. The degree of cyanoethylation was calculated from:

Degree of cyanoethylation $($ mole $\%)=\frac{162 \times N}{42-1.59 \times N}$

Moisture Regain. After vacuum-drying for $3 \mathrm{hr}$ at room temperature, sample fabrics were conditioned at $20^{\circ} \mathrm{C}$ and $65 \%$ R.H. until a constant weight was reached, and weighed. Then, the samples were weighed after drying for $24 \mathrm{hr}$ at $40^{\circ} \mathrm{C}$ in high vacuum to obtain the moisture regain.

Resin Treatment. Dimethylol ethyleneurea (DMEU) (Sumitex Resin 901) and trimethylolmelamine (TMM) (Sumitex Resin M3) were used as crosslinking agents and Sumitex Accelerator $\mathrm{KX}$ and ACX were used as catalysts. Sample fabrics were padded with the solution of resin and catalyst, to $80 \%$ wet pick up. Drying and curing were performed at $80^{\circ} \mathrm{C}$ for $30 \mathrm{~min}$ and $150^{\circ} \mathrm{C}$ for $5 \mathrm{~min}$, respectively. After curing, the fabric samples were immersed in $0.3 \%$ solution of soap at $50^{\circ} \mathrm{C}$, then rinsed with water at $50^{\circ} \mathrm{C}$, and dried.

Resin Add-On. The add-on of crosslinking agent is determined as follows. The resin-treated sample dried at $40^{\circ} \mathrm{C}$ in high vacuum was weighed $\left(W_{0}\right)$, then immersed in an aqueous solution containing $0.25 \%$ 'Maruseru' soap and $0.25 \%$ anhydrous sodium carbonate for $5 \mathrm{~min}$ at $90^{\circ} \mathrm{C}$, rinsed thoroughly in hot water, dried at $40^{\circ} \mathrm{C}$ in high vacuum, and weighed $\left(W_{1}\right)$. The sample was next immersed in $0.25 \%$ hydrochloric acid for $60 \mathrm{~min}$ at $90^{\circ} \mathrm{C}$, rinsed thoroughly in hot water, dried at $40^{\circ} \mathrm{C}$ in high vacuum, and weighed $\left(W_{2}\right)$. Resin add-on was calculated from the following equations:

Unfixed resin $(\%)=\frac{W_{0}-W_{1}}{W_{2}} \times 100$
Fixed resin $(\%)=\frac{W_{1}-W_{2}}{W_{2}} \times 100$

Total resin add-on $(\%)=$ Unfixed resin $(\%)+$ Fixed resin $(\%)$

Tensile Properties of Warp Yams. Tensile strength and elongation of the warp yarns taken from fabrics were measured by a Tensilon UTM Type III. Specimen length was $30 \mathrm{~mm}$. The extension speed was $10 \mathrm{~mm} / \mathrm{min}$.

Crease Recovery. The crease recovery of fabric $(4 \mathrm{~cm} \times 1 \mathrm{~cm}$ : the longer dimension was along the warp direction) was measured using a Monsanto type tester. A weight of $500 \mathrm{~g}$ was applied for 5 min and the crease angle $\left(\alpha^{\circ}\right)$ was measured at 5 min after unloading. Crease recovery was calculated by:

Crease recovery $(\%)=\frac{\alpha}{180} \times 100$

Abrasion Resistance. Flex- and edge-abrasion resistances were measured with a custom type fabric abrasion tester.

Results and Discussion

The physical properties of cotton fabrics treated with alkali and acrylonitrile are shown in Table 1 and 2. Table 2 includes the results on the resintreated fabrics.

The cotton fabrics decrystallized by the alkaliacrylonitrile treatment give no change in tensile strength of warp yarn, but exhibit an increase in elongation. It is notable that abrasion resistance of the fabrics increased in the order, untreated $<$ mercerized < decrystallized, although the mercerized or decrystallized fabric is somewhat thicker than original fabric. This improvement of abrasion

Table 1 Physical Properties of Decrystallized Cotton.

\begin{tabular}{|c|c|c|c|c|c|}
\hline \multirow{3}{*}{ Sample } & \multirow{3}{*}{$\begin{array}{c}\text { Thickness } \\
\text { mm }\end{array}$} & \multicolumn{2}{|c|}{ Warp Tensile Properties } & \multirow{2}{*}{\multicolumn{2}{|c|}{$\begin{array}{c}\text { Abrasion Resistance, } \\
\text { cycle }\end{array}$}} \\
\hline & & Strength, & Elongation & & \\
\hline & & g & $\theta$ & Flex- & Edge- \\
\hline Original cotton & 0.228 & 267 & 6.5 & 688 & 1289 \\
\hline Mercerized cotton ${ }^{a}$ & 0.282 & 265 & 8.7 & 736 & 1763 \\
\hline Decrystallized cotton ${ }^{b}$ & 0.315 & 260 & 9.3 & 792 & 2937 \\
\hline
\end{tabular}

a Immersed in $5.4 \mathrm{~N} \mathrm{NaOH}$ for 30 min at $15^{\circ} \mathrm{C}$.

b Immersed in $5.4 \mathrm{~N} \mathrm{NaOH}$ for $30 \mathrm{~min}$ at $15^{\circ} \mathrm{C}$ and treated with acrylonitrile for $30 \mathrm{~min}$ at $20^{\circ} \mathrm{C}$. Degree of cyanoethylation, $3.8-4.6$ mole $\%$. 
Table 2 Properties of Resin-Treated Cotton Fabrics. ${ }^{a}$

\begin{tabular}{|c|c|c|c|c|c|c|c|c|}
\hline \multirow[b]{3}{*}{ Sample } & \multirow{3}{*}{$\begin{array}{c}\text { Shrinkage } \\
\% \\
\text { Warp } \times \text { Filling }\end{array}$} & \multirow{2}{*}{\multicolumn{2}{|c|}{$\begin{array}{c}\text { Crease Recovery } \\
\% \\
\end{array}$}} & \multirow{3}{*}{$\begin{array}{l}\text { Resin } \\
\text { Add-on } \\
\%\end{array}$} & \multirow{3}{*}{$\begin{array}{l}\text { Fixed } \\
\text { Resin } \\
\%\end{array}$} & \multicolumn{2}{|c|}{ Tensile Properties } & \multirow{3}{*}{$\begin{array}{l}\text { Moisture } \\
\text { Regain } \\
\%\end{array}$} \\
\hline & & & & & & Strength & Elongation & \\
\hline & & Dry & Wet & & & $\mathrm{g}$ & $\%$ & \\
\hline \multicolumn{9}{|l|}{ No Resin } \\
\hline Control & - & 39 & 37 & - & - & 267 & 6.5 & 7.8 \\
\hline Mercerized ${ }^{\mathbf{b}}$ & $17 \times 5$ & 39 & 50 & - & 一 & 265 & 8.7 & 11.1 \\
\hline $\begin{array}{l}\text { Decrystallized } \\
\text { CN-3.9 mole } \%\end{array}$ & $27 \times 12$ & 22 & 56 & - & - & 260 & 9.3 & 12.1 \\
\hline \multicolumn{9}{|c|}{ Resin treatment (10\% DMEU) } \\
\hline Mercerized $^{\mathrm{b}}$ & $22 \times 7$ & 71 & 70 & 5.8 & 5.8 & 116 & 5.0 & 8.5 \\
\hline $\begin{array}{l}\text { Decrystallized }^{c} \\
\text { CN-1.9 mole\% }\end{array}$ & $24 \times 6$ & 73 & 82 & 6.0 & 5.8 & 105 & 6.3 & 10.0 \\
\hline 5.6 mole $\%$ & $28 \times 9$ & 64 & 75 & 6.9 & 6.8 & 79 & 6.5 & 10.7 \\
\hline 9.4 mole\% & $35 \times 13$ & 64 & 86 & 7.3 & 6.5 & 80 & 7.1 & 10.8 \\
\hline
\end{tabular}

a Catalyst; Sumitex accelerator $\mathrm{KX} 15 \%$. All treatment is done in a slack state.

b Immersed in $5.4 \mathrm{~N} \mathrm{NaOH}$ for $30 \mathrm{~min}$ at $15^{\circ} \mathrm{C}$.

c Immersed in $5.4 \mathrm{~N} \mathrm{NaOH}$ for $30 \mathrm{~min}$ at $15^{\circ} \mathrm{C}$ and treated with acrylonitrile at $20^{\circ} \mathrm{C}$.

resistance of the decrystallized cotton fabric may be advantageous in reducing the decrease in abrasion resistance due to crosslinking.

Kullmann et al. ${ }^{5}$ examined the effects of the crosslinking with DMEU on several modified cotton fabrics, such as carboxymethylated, carboxyethylated, hydroxyethylated and methylated cottons. The treating solution used by them contained $8 \%$ DMEU, $0.5 \%$ zinc nitrate hexahydrate, and $0.05 \%$ acetic acid. For cyanoethylation of cottons, Kullmann et al. used $2 \%$ sodium hydroxide and carried out reaction with acrylonitrile at $55-60^{\circ} \mathrm{C}$.

In our method, cotton fabrics were impregnated with $5.4 \mathrm{~N} \mathrm{NaOH}$ solution and immersed into acrylonitrile at $20^{\circ} \mathrm{C}$. As shown in Table 2 , the crosslinking treatment was applied to the fabrics with various degrees of cyanoethylation, i.e., 1.9 , 5.6 and 9.4 mole\%. The treating solution included $10 \%$ DMEU and $15 \% \mathrm{KX}$.

The dry crease recovery of the cotton fabric treated with alkali-acrylonitrile without further crosslinking is lower than that of the untreated or mercerized fabric. On the contrary, the wet crease recovery value is increased by decrystallization. As shown in Table 2, the dry crease recovery value of the crosslinked fabric decreases and the wet value increases as the cyanoethylation proceeds. As the degree of substitution increases, the tensile strength seems to decrease, but the elongation does not change significantly and the moisture regain increases. The increased accessibility may be due to disruption of the hydrogen bonds. The presence of the cyanoethyl groups prevents reformation of hygrogen bonds on drying, which can occur to some extent with mercerized cotton.

Moisture regain of the decrystallized cotton fabrics is higher than original and mercerized fabrics as shown in Table 2 . They retain high moisture regain even after crosslinking.

Resin add-on is altered using the treating solution containing 5, 10 and 17\% DMEU, and the results are shown in Table 3 . The decrystallized cotton fabrics give lower dry crease recovery than original and mercerized cotton at the same resin add-on. But the wet crease recovery of the decrystallized cotton fabrics is nearly equal to that of original cotton.

The minimum crease recovery required for good tumble-dry wash-wear behavior was reported to be $70 \% .^{6}$ DMEU solution in $7-8 \%$ is required for the decrystallized cotton fabric to obtain dry crease recovery of $70 \%$.

At the same resin add-on, the tensile strength of the warp yarn of original cotton fabric is higher than that of mercerized or decrystallized cotton. On the other hand, the elongation increases in the following order: original cotton $<$ mercerized 
Table 3 Crosslinking of NaOH-AN Treated Fabrics with Various Concentration of DMEU.

\begin{tabular}{|c|c|c|c|c|c|c|c|c|c|}
\hline \multicolumn{2}{|l|}{ Sample } & \multirow{3}{*}{$\begin{array}{c}\text { Shrinkage } \\
\% \\
\mathrm{~W} \times \mathrm{F}\end{array}$} & \multirow{2}{*}{\multicolumn{2}{|c|}{$\begin{array}{c}\text { Crease Recovery } \\
\%\end{array}$}} & \multirow{3}{*}{$\begin{array}{c}\text { Resin } \\
\text { Add-on } \\
\%\end{array}$} & \multirow{3}{*}{$\begin{array}{c}\text { Fixed } \\
\text { Resin } \\
\%\end{array}$} & \multicolumn{2}{|c|}{ Tensile Properties } & \multirow{3}{*}{$\begin{array}{l}\text { Moisture } \\
\text { Regain } \\
\text { of }\end{array}$} \\
\hline \multirow{2}{*}{$\begin{array}{l}\text { Pre- } \\
\text { Treatment }\end{array}$} & \multirow[b]{2}{*}{ DMEU,\% } & & & & & & Strength & Elongation & \\
\hline & & & Dry & Wet & & & $\mathrm{g}$ & $\%$ & \\
\hline Control & No & - & 39 & 37 & - & - & 267 & 6.5 & 7.8 \\
\hline Mercerized $^{a}$ & resin & $17 \times 5$ & 39 & 50 & - & - & 265 & 8.7 & 11.1 \\
\hline $\begin{array}{c}\text { Decrystallized }^{c} \\
\text { CN-3.9 mole\% }\end{array}$ & & $27 \times 12$ & 22 & 56 & - & - & 260 & 9.3 & 12.1 \\
\hline Control & 5 & $2 x-5$ & 76 & 75 & - & 3.4 & 163 & 3.3 & 6.3 \\
\hline Mercerized $^{a}$ & & $16 \times 1$ & 75 & 68 & $\underline{-}$ & 3.0 & 142 & 5.4 & 9.3 \\
\hline Mercerized $^{b}$ & & $16 \times 1$ & 63 & 69 & - & 3.4 & 143 & 5.3 & 9.9 \\
\hline Decrystallized $^{c}$ & & $18 \times 2$ & 57 & 79 & - & 4.1 & 133 & 7.2 & 11.4 \\
\hline Control & 10 & $3 x-4$ & 83 & 80 & 6.8 & 6.2 & 136 & 2.5 & 5.4 \\
\hline Mercerized $^{a}$ & & $15 \times 2$ & 77 & 68 & 5.5 & 5.5 & 102 & 4.9 & 8.3 \\
\hline Mercerized $^{b}$ & & $15 \times 2$ & 77 & 75 & 6.3 & 6.2 & 99 & 4.7 & 8.7 \\
\hline Decrystallized ${ }^{c}$ & & $26 \times 12$ & 67 & 82 & 6.9 & 6.5 & 94 & 7.6 & 9.8 \\
\hline Control & 17 & $1 x-5$ & 91 & 85 & 15.1 & 13.8 & 124 & 2.3 & 5.2 \\
\hline Mercerized $^{\mathbf{a}}$ & & $15 \times 2$ & 89 & 79 & 10.9 & 10.3 & 78 & 4.3 & 7.2 \\
\hline Mercerized $^{b}$ & & $15 \times 2$ & 80 & 79 & 11.0 & 10.3 & 81 & 4.9 & 7.8 \\
\hline Decrystallized $^{\mathfrak{c}}$ & & $18 \times 2$ & 84 & 81 & 12.1 & 11.5 & 73 & 7.5 & 9.4 \\
\hline
\end{tabular}

a Immersed in $5.4 \mathrm{~N} \mathrm{NaOH}$ for $30 \mathrm{~min}$ at $15^{\circ} \mathrm{C}$.

b Not dried before resin treatment.

c Immersed in $5.4 \mathrm{~N} \mathrm{NaOH}$ for $30 \mathrm{~min}$ at $15^{\circ} \mathrm{C}$ and treated with acrylonitrile at $20^{\circ} \mathrm{C}$. Degree of cyanoethylation is $5-6$ mole\%.

Table 4 Properties of Resin-Treated Cotton Fabrics Having Same Degree of Dry Crease Recovery.

\begin{tabular}{|c|c|c|c|c|c|c|c|c|}
\hline \multicolumn{2}{|l|}{ Sample } & \multirow{2}{*}{\multicolumn{2}{|c|}{$\begin{array}{c}\text { Crease Recovery } \\
\%\end{array}$}} & \multirow{3}{*}{$\begin{array}{l}\text { Resin } \\
\text { Add-on } \\
\%\end{array}$} & \multirow{3}{*}{$\begin{array}{c}\text { Fixed } \\
\text { Resin } \\
\%\end{array}$} & \multicolumn{2}{|c|}{ Tensile Properties } & \multirow{3}{*}{$\begin{array}{c}\text { Moisture } \\
\text { Regain } \\
\text { \% }\end{array}$} \\
\hline \multirow{2}{*}{$\begin{array}{l}\text { Pre- } \\
\text { Treatment }\end{array}$} & \multirow[b]{2}{*}{ DMEU,\% } & & & & & Strength & $\overline{\text { Elongation }}$ & \\
\hline & & Dry & Wet & & & $\mathrm{g}$ & $\%$ & \\
\hline Untreated & 10 & 82 & 77 & 8.3 & 6.9 & 142 & 2.5 & 5.3 \\
\hline Mercerized $^{\mathrm{a}}$ & 17 & 89 & 79 & 10.9 & 10.3 & 78 & 4.3 & 7.2 \\
\hline Decrystallized $^{\text {b }}$ & 17 & 84 & 81 & 12.1 & 11.5 & 73 & 7.5 & 9.4 \\
\hline Untreated & 5 & 76 & 75 & 3.4 & 3.4 & 163 & 3.3 & 6.3 \\
\hline Mercerized $^{\mathrm{a}}$ & 10 & 77 & 68 & 5.5 & 5.5 & 102 & 4.9 & 8.3 \\
\hline Decrystallized $^{\mathrm{b}}$ & 10 & 67 & 82 & 6.9 & 6.5 & 94 & 7.6 & 9.8 \\
\hline
\end{tabular}

a Immersed in $5.4 \mathrm{~N} \mathrm{NaOH}$ for 30 min at $15^{\circ} \mathrm{C}$.

b Immersed in $5.4 \mathrm{~N} \mathrm{NaOH}$ for $30 \mathrm{~min}$ at $15^{\circ} \mathrm{C}$ and treated with acrylonitrile for $30 \mathrm{~min}$ at $20^{\circ} \mathrm{C}$. Degree of cyanoethylation, $5-6$ mole\%.

cotton $<$ decrystallized cotton.

Properties of the resin-treated cotton fabrics having the same degree of dry crease recovery are shown in Table 4. To compensate the disruption of bonds due to decrystallization, higher resin addon was required to obtain the same degree of crease recovery as original cotton. Larger loss in the tensile strength was caused, but the elongation remained at a high value. If the decrystallized fabric is stretched and the resin treatment is applied, the decrease in tensile strength may be reduced.

The crosslinking with DMEU solution for alkaliacrylonitrile treated cotton in slack state did not 
improve the tensile strength. As pointed out by Kullmann et al., ${ }^{5}$ the effect of substitution of hydroxyl groups of cellulose on the reactivity toward DMEU may be dependent on the nature of the substituent and the swellability of the etherified fiber. In other words, if the substituent is inert to DMEU, the reactivity toward DMEU decreases. Besides, the efficiency of crosslinking may be decreased by the distended cellulose structure. The most reactive site on cellulose molecule is first occupied with substituent group. When the decrystallization and crosslinking treatment is performed, it is desirable to take into account these circumstances.

The crosslinking treatment for the alkali-acrylonitrile treated fabrics was also carried out using $10 \%$ TMM and Sumitex Accelerator ACX. The results were compared with those for samples treated with 10\% DMEU in Table 5. For the samples crosslinked with TMM, the crease recovery and the loss in tensile strength are smaller, and the elongation and moisture regain are higher than those with DMEU.

Finally the cotton fabrics treated with DMEU were subjected to alkali-acrylonitrile treatment.
Results obtained are shown in Table 6.

Plot $z^{7}$ reported that, when the cotton fabrics treated with a crease-resistant finish were subjected to the proionged contact with $20 \%$ sodium hydroxide solution, the dry crease recovery and the water resistance imparted by the finish disappeared almost completely, whereas the wet crease recovery was hardly affected by this treatment.

As shown in Table 6, a considerable loss in dry crease recovery of the fabrics treated with $10 \%$ DMEU is caused by the treatment with alkaliacrylonitrile. Tensile strength and elongation of the crosslinked fabrics are increased by the alkaliacrylonitrile treatment. In addition, the moisture regain increases to a value higher than $10 \%$. In the case of $17 \%$ DMEU solution, the influence of alkali-acrylonitrile treatment on the resin-treated cotton fabrics is less than that with $10 \%$ DMEU solution. But the tensile strength, elongation and moisture regain of the treated fabrics are larger than those of the crosslinked control fabric. The tensile stress distribution suppressed by the rigid and brittle joints introduced by crosslinking agents is relaxed by the alkali-acrylonitrile treatment.

Table 5 Crosslinking of NaOH-AN Treated Fabrics with DMEU and TMM.

\begin{tabular}{|c|c|c|c|c|c|c|c|c|}
\hline \multicolumn{2}{|l|}{ Sample } & \multirow{2}{*}{\multicolumn{2}{|c|}{$\begin{array}{c}\text { Crease Recovery } \\
\% \\
\end{array}$}} & \multirow{3}{*}{$\begin{array}{c}\text { Resin } \\
\text { Add-on } \\
\%\end{array}$} & \multirow{3}{*}{$\begin{array}{c}\text { Fixed } \\
\text { Resin } \\
\%\end{array}$} & \multicolumn{2}{|c|}{ Tensile Properties } & \multirow{3}{*}{$\begin{array}{c}\text { Moisture } \\
\text { Regain } \\
\%\end{array}$} \\
\hline \multirow{2}{*}{$\begin{array}{l}\text { Pre- } \\
\text { Treatment }\end{array}$} & \multirow[b]{2}{*}{ Resin } & & & & & Strength & Elongation & \\
\hline & & Dry & Wet & & & $g$ & $\%$ & \\
\hline Untreated & \multirow{3}{*}{$\begin{array}{l}\text { No } \\
\text { Resin }\end{array}$} & 39 & 37 & $\rightarrow$ & 一 & 267 & 6.5 & 7.8 \\
\hline Mercerized $^{a}$ & & 39 & 50 & - & - & 265 & 8.7 & 11.1 \\
\hline $\begin{array}{l}\text { Decrystallized } \\
\text { CN-3.9 mole\% }\end{array}$ & & 22 & 56 & - & - & 260 & 9.3 & 12.1 \\
\hline Mercerized $^{a}$ & \multirow{5}{*}{$\begin{array}{l}\mathrm{TMM}^{d} \\
10 \%\end{array}$} & 66 & 63 & 5.7 & 5.2 & 183 & 5.7 & 8.6 \\
\hline Mercerized ${ }^{\text {b }}$ & & 57 & 61 & 6.5 & 6.0 & 168 & 5.1 & 9.0 \\
\hline Decrystallized $\mathrm{d}^{\mathfrak{c}}$ & & & & & & & & \\
\hline CN-1.9 mole\% & & 47 & 70 & 6.2 & 5.8 & 178 & 5.9 & 10.2 \\
\hline CN-5.6 mole\% & & 47 & 73 & 6.9 & 5.9 & 173 & 6.3 & 11.1 \\
\hline Untreated & \multirow{4}{*}{$\begin{array}{l}\text { DMEU } \\
10 \%\end{array}$} & 83 & 80 & 6.8 & 6.2 & 136 & 2.5 & 5.4 \\
\hline Mercerized $^{a}$ & & 77 & 68 & 5.5 & 5.5 & 102 & 4.9 & 8.3 \\
\hline Mercerized ${ }^{b}$ & & 77 & 75 & 6.3 & 6.2 & 99 & 4.7 & 8.7 \\
\hline $\begin{array}{l}\text { Decrystallized } \\
\text { CN-5.0 mole\% }\end{array}$ & & 67 & 82 & 6.9 & 6.5 & 94 & 7.6 & 9.8 \\
\hline
\end{tabular}

a Immersed in $5.4 \mathrm{~N} \mathrm{NaOH}$ for $30 \mathrm{~min}$ at $15^{\circ} \mathrm{C}$.

b Not dried before resin treatment.

- Immersed in $5.4 \mathrm{~N} \mathrm{NaOH}$ for $30 \mathrm{~min}$ at $15^{\circ} \mathrm{C}$ and treated with acrylonitrile at $20^{\circ} \mathrm{C}$.

d Catalyst; ACX $10 \%$.

e Catalyst; KX $15 \%$. 
Table 6 Influence of NaOH-AN Treatment on Resin-Treated Cotton Fabrics.

\begin{tabular}{|c|c|c|c|c|c|c|c|c|}
\hline \multicolumn{2}{|c|}{ Sample } & \multirow{2}{*}{\multicolumn{2}{|c|}{$\begin{array}{c}\text { Crease Recovery } \\
\% \\
\end{array}$}} & \multirow{3}{*}{$\begin{array}{l}\text { Resin } \\
\text { Add-on } \\
\%\end{array}$} & \multirow{3}{*}{$\begin{array}{c}\text { Fixed } \\
\text { Resin } \\
\%\end{array}$} & \multicolumn{2}{|c|}{ Tensile Properties } & \multirow{3}{*}{$\begin{array}{l}\text { Moisture } \\
\text { Regain } \\
\%\end{array}$} \\
\hline \multirow{2}{*}{$\begin{array}{l}\text { Resin } \\
\text { Treatment }\end{array}$} & \multirow{2}{*}{$\begin{array}{l}\mathrm{NaOH}-\mathrm{AN} \\
\text { Treatment }^{\mathrm{a}}\end{array}$} & & & & & Strength & Elongation & \\
\hline & & Dry & wet & & & & & \\
\hline \multirow{3}{*}{$\begin{array}{l}\text { No } \\
\text { Resin }\end{array}$} & - & 39 & 37 & - & - & 267 & 6.5 & 7.8 \\
\hline & $\mathrm{NaOH} 30 \mathrm{~min}$ & 39 & 50 & - & - & 265 & 8.7 & 11.1 \\
\hline & $\begin{array}{ll}\mathrm{NaOH} & 30 \mathrm{~min} \\
\mathrm{AN} & 30 \mathrm{~min}\end{array}$ & 22 & 56 & - & - & 260 & 9.3 & 12.1 \\
\hline \multirow{5}{*}{$\begin{array}{l}\text { DMEU } \\
10 \%\end{array}$} & - & 82 & 77 & 8.3 & 6.9 & 142 & 2.5 & 5.3 \\
\hline & $\mathrm{NaOH} 15 \mathrm{~min}$ & 76 & 74 & 8.1 & 5.7 & 152 & 4.4 & 6.3 \\
\hline & $\mathrm{NaOH} 30 \mathrm{~min}$ & 54 & 59 & 7.9 & 4.7 & 191 & 4.3 & 7.2 \\
\hline & $\begin{array}{ll}\mathrm{NaOH} & 15 \mathrm{~min} \\
\mathrm{AN} & 30 \mathrm{~min}\end{array}$ & 60 & 63 & 8.9 & 8.5 & 191 & 6.3 & 9.8 \\
\hline & $\begin{array}{ll}\mathrm{NaOH} & 30 \mathrm{~min} \\
\mathrm{AN} & 30 \mathrm{~min}\end{array}$ & 48 & 60 & 9.3 & 8.8 & 161 & 6.2 & 11.8 \\
\hline \multirow{5}{*}{$\begin{array}{l}\text { DMEU } \\
17 \%\end{array}$} & - & 86 & 83 & 14.0 & 11.4 & 137 & 2.3 & 5.2 \\
\hline & $\mathrm{NaOH} 15$ min & 79 & 85 & 13.4 & 11.2 & 144 & 2.4 & 5.0 \\
\hline & $\mathrm{NaOH} 30 \mathrm{~min}$ & 81 & 79 & 11.9 & 9.9 & 143 & 2.2 & 5.0 \\
\hline & $\begin{array}{ll}\mathrm{NaOH} & 15 \mathrm{~min} \\
\mathrm{AN} & 30 \mathrm{~min}\end{array}$ & 72 & 70 & 12.6 & 10.1 & 158 & 3.2 & 7.7 \\
\hline & $\begin{array}{ll}\mathrm{NaOH} & 30 \mathrm{~min} \\
\mathrm{AN} & 30 \mathrm{~min}\end{array}$ & 63 & 70 & 12.8 & 9.5 & 164 & 3.8 & 7.9 \\
\hline
\end{tabular}

a Immersed in $5.4 \mathrm{~N} \mathrm{NaOH}$ at $15^{\circ} \mathrm{C}$ and treated with acrylonitrile at $20^{\circ} \mathrm{C}$.

This leads to a more flexible structure and to restoration of tensile strength.

As shown above, the decrystallization by the alkali-acrylonitrile treatment did not contribute to the prevention of the decrease of tensile strength of cotton by crosslinking, although it increased the abrasion resistance of cotton fabrics. It is noted that the decrystallized cotton fabrics showed low dry crease recovery, although its wet crease recovery increased. The decrystallized cotton fabrics showed considerably higher stiffness than the untreated or mercerized cotton fabric. It is presumed that this high stiffness of the decrystallized cotton fabrics causes a decrease in the dry crease recovery. As regards to this problem, we recently found ${ }^{8}$ a possibility to obtain highly accessible cotton fabric retaining the softness of original cotton fabric by a treatment with $\mathrm{NaOH}$ and acrylonitrile in the presence of ethanol. With an expectation that this modification may contribute to reduce the decrease in tensile strength of cotton fabric by crosslinking, experiments are now being in progress.

\section{Acknowledgement}

The authors wish to thank the International Institute for Cotton for financial assistance and Dr. F. H. Burkitt for his helpful discussions. The authors also wish to thank Professor A. Nakajima for his valuable discussions.

\section{References}

1) W. Tsuji and M. Imai; Ann. Rep. Res. Inst. Chem. Fibers, Kyoto Univ., 20, 9 (1963); idem., Bull. Inst. Chem. Res., Kyoto Univ., 44, 183 (1966).

2) W. Tsuji, A. Hirai and M. Hosono; J. Appl. Polym. Sci., 20, 2837 (1976).

3) A. Hirai, W. Tsuji, R. Kitamaru and M. Hosono; J. Appl. Polym. Sci, 20, 3365 (1976).

4) W. Tsuji; Bull. Inst. Chem. Res., Kyoto Univ., 49, 69 (1971).

5) R. M. H. Kullmann, J. G. Frick, Jr., R. M. Reinhardt and J. D. Reid, Text. Res. J., 31, 877 (1961).

6) R. Steel, Text. Res, J., 30, 37 (1960).

7) E. Plotz, J. Text. Inst. Proc., 53, 51 (1962).

8) A. Hirai, A. Nakajima and W. Tsuji; Semi-Ann. Meet., Soc. Fiber Sci. \& Techn., Japan, 1976, preprint, p103. 